by Zhang Meiliang ${ }^{1}$, Cheng Hai ${ }^{2}$, Yuan Daoxian ${ }^{1}$, Lin Yushi $^{1}$, Qin Jiaming ${ }^{1}$, Wang Hua ${ }^{1}$, Feng Yumei ${ }^{1}$, Tu Lingling ${ }^{1}$, and Zhang Huiling ${ }^{1}$

\title{
High-resolution climate records from two stalagmites in Qixin Cave, southern Guizhou, and Heinrich events during the last glacial period
}

\author{
1 Karst Dynamics Laboratory, Institute of Karst Geology, CAGS, Guilin 541004, China. E-mail: mlzh@karst.edu.cn \\ 2 Department of Geology and Geophysics, University of Minnesota, MN 55455, USA.
}

The time sequence of high-resolution paleoclimatic changes since the last glacial period-60,500 yr B.P.has been reconstructed with high-precision TIMS-U series dates and analyses of the oxygen isotopes from Q4 and Q6 stalagmites of the Qixin Cave in southern Guizhou. Comparative analyses of $\delta^{18} \mathrm{O}$ curves from the GISP2' ice core and the two stalagmites shows that the depositional records of the Dansgaard-Oeschger cycle events 1-18 and Heinrich's events H1-H5 from the records of the two stalagmites reflect rapid climate changes over a short time scale since the last glacial stage, and indicates the precise boundary lines at which the cold events occurred. The study results have shown that the records of the cold and warm events from the two stalagmites since 60,500 yr B.P. are the reflection of the paleo-monsoon circulation. Changes are clearly affected by the climate oscillation of the North Atlantic Ocean, and indicate that they have a strong teleconnection with the paleoclimate changes that occurred in the North Polar region.

The records of $\delta^{18} O$ from the $Q 4$ and $Q 6$ stalagmites indicate that the $\delta^{18} \mathrm{O}$ values from $60,590 \mathrm{yr}$ B.P. to 11,290 yr B.P. changed from a more negative (or lighter) drift to a heavier or positive drift trend in the last glacial period. The data reflect the weakening of the Asian summer monsoon and the climate which generally became drier and cooler.

\section{Introduction}

The imprint of Heinrich's cold events has been discovered in the study records of Loess deposits, and of sporo-pollen from the South China Sea shelf and inland lakes of China (Guo Zhengtang et al., 1996; Lu Houyuan et al., 1996; Gu Zhaoyan et al., 1998; Bond G. et al., 1992; Porter, S. and An Z.S., 1995) in the area of the Eastern Asian monsoon. The records of the Heinrich cold events during the last glacial period have also been found by paleo-environment research on cave stalagmites. For instance, all the Heinrich cold events have been recorded from stalagmites of Panglong Cave and
Xiangshui Cave in Guilin, Yaman Cave in Guizhou, and Tangshan Cave in Nanjing (Zhang Meiliang et al., 1998; Yuan Daoxian et al., 1999; Wang Yongjin et al., 2001; Jeffrey A.D. et al., 1998). However, until now, the few geological records of the cold events from stalagmites during the last glacial period were only compared with the dry-cold events-Heinrich's cold events in the DansgaardOeschger cycles of the Greenland ice core (Bond G. et al., 1993). Precise dates from various sediments and the index of the high-resolution paleoclimate must be analyzed and studied in order to understand the climatic change mechanisms, strength, scales and the formation time of cold events in the Asian monsoon region influenced by Heinrich's cold events. The continuous records of the high-resolution paleoclimate changes from Q4 and Q6 stalagmites of the Qixin Cave in southern Guizhou since 60,500 yr B.P. have revealed the high frequency oscillation characteristics and climate changes of the Asian monsoon region in South China during the last glacial period. Compared with the Heinrich cold events in the DansgaardOeschger cycles of the GISP2 ice core, the short time scales of the climate undulation from the stalagmite records in the region of the Asian monsoon are obviously related to global climate change, but the regional climatic change characteristics still exist.

\section{Collection and analysis of samples}

Qixin Cave is situated $\sim 1.5 \mathrm{~km}$ southwest of Kaiyu village, $100 \mathrm{~km}$ to the southwest of Duyun city, Guizhou (Figure 1). It is located in the southeast of the Yunnan and Guizhou Plateau, and belongs to a concentrated cluster-depression area of the karst plateau in the southeast monsoon area of the subtropical zone. The average air temperature in the area is about $15.3^{\circ} \mathrm{C}$, the average annual rainfall is $1089.3 \mathrm{~mm}$, and the annual evaporation rate is about $1550.6 \mathrm{~mm}$, which indicate inadequate humidity (Gao Daode et al., 1986). The area is weakly affected by the intensity of the Eastern Asian summer monsoon and India monsoon, and the Eastern Asian winter monsoon usually prevails.

Samples were taken from the Q4 and Q6 stalagmites, which are $50 \mathrm{~cm}$ and $244.5 \mathrm{~cm}$ high respectively. The diameters of the two stalagmites are $12 \mathrm{~cm}$ and $9 \mathrm{~cm}$ respectively. Sections across the Q4 and Q6 stalagmites show clear sediment laminae after cutting along their central growth axis. The calcite crystals of the stalagmites are very fine, grey and greyish white, and consist of $0.1 \sim 1.5 \mathrm{~mm}$ thick micro grain and needle calcite with clear sediment laminae and without obvious recrystallization. Based on the texture and fabric characteristics, the sections of the two stalagmites can be divided into multi-sediment cycles, with thickness of each cycle ranging $2.3 \mathrm{~cm}$ to $20 \mathrm{~cm}$. Each cycle has 3 to 6 micro-lamina groups or subcycles. The two stalagmites indicate continual deposition.

The samples for the oxygen isotopes were taken along the central growth axis of the stalagmites. The sampling interval for the Q4 


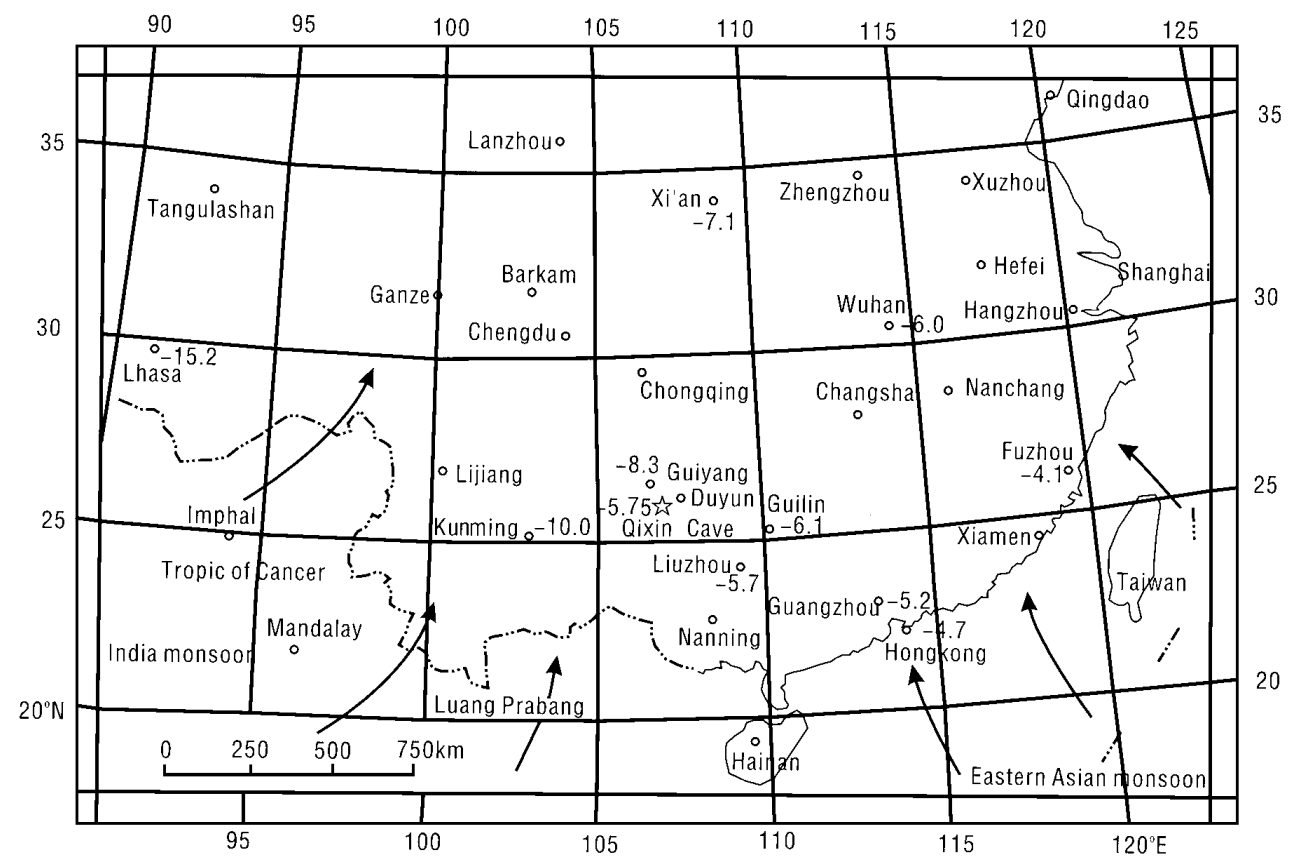

Figure 1 Location of Qixin Cave in southern Guizhou and moving route of the moisture source of summer monsoon in South China. The data are the annual average $\delta^{18} \mathrm{O}$ values of the precipitation ( $\mathrm{Li}$ Bin et al., 2000; Zheng Shuhui et al., 1983; Lin Yushi et al., 2001; Yuan Daoxian et al., 1999).

\section{4 moving route of summer monsoon \\ is Qixin Cave in Guizhou.}

stalagmite is $0.2 \mathrm{~cm}$ or $0.5 \mathrm{~cm}$, which allowed taking 149 oxygen isotopes and 4 parallel samples. We collected 11 samples for TIMS$\mathrm{U}$ series dating. The sampling interval for the Q6 stalagmite is 0.5 $\mathrm{cm}$ or $2 \mathrm{~cm}$, allowing sampling 313 oxygen isotopes and taking 4 parallel samples. We collected 11 samples for TIMS-U series dating.

The samples from the two stalagmites were dated by using the TIMS-U series method (Thermal Ionization Mass spectrometric instrument of Finnigan MAT262-RPQ). The age dating was performed by Dr. Cheng Hai in the Department of Geology and Geophysics, University of Minnesota, USA. The ${ }^{229} \mathrm{Th}^{233} \mathrm{U}^{236} \mathrm{U}$ was used with the diluent material. The error of dating ages is within $1 \%$ $(2 \sigma)$.

The analyses of carbon and oxygen isotopes were performed by the Isotope Laboratory, Institute of Karst Geology, Guilin, China, using a VG MM-903 gas mass spectrometer. Samples were reacted with phosphoric acid at $72^{\circ} \mathrm{C}$ to be converted to $\mathrm{CO}_{2}$. Values of the carbon and oxygen isotopes are reported in per mil related to SMOW and PDB with analytical precision within 0.1 per mil.

\section{Chronology and $\delta^{18} \mathrm{O}$ records of the stalagmites}

The ages of TIMS-U series dates from the Q4 and Q6 stalagmites (Table 1, Figure 2) are from 60,500 yr B.P. to 11,290 yr B.P., following the normal order according to sedimentary sequence of the stalagmites (see Table 1), indicating that the age data were reasonable. The characteristics of the texture, fabric and lithology and lamina shape from the sedimentary sections of the two stalagmites show that the dripping rate from the top of the cave was stable, indicating that the two stalagmites were continuous deposits on the whole. The time sequences were obtained on the basis of TIMS-U series dating ages from the Q4 and Q6 stalagmites. The TIMS-U series age of $28,080 \mathrm{yr}$ B.P at $18 \mathrm{~cm}$ from the top of the Q4 stalagmite and 94.5 $\mathrm{cm}$ from the top of the Q6 stalagmite can be taken as the boundary age of MIS2/3. However, the TIMS-U series age of $11,300 \mathrm{yr}$ B.P. at $2.5 \mathrm{~cm}$ from the top of the Q6 stalagmite can be taken as the boundary age of MIS1/2 or Termination 1 of the last glacial period.

The curves of the oxygen isotope records from the Q4 and Q6 stalagmites are shown in Figure 2. The curve changes of the oxygen isotopes from the two stalagmites are nearly identical. The average $\delta^{18} \mathrm{O}$ values of the Q4 and Q6 stalagmites since 60,500yr B.P. dur- ing the last glacial period are $-5.85 \%$ (PDB) and $-5.80 \%$ (PDB), respectively. The average isotope values of the two stalagmites are very close to $-5.74 \%$ ( $\mathrm{SMOW}$ ) - the oxygen isotope value (analyzed in 2000) of the present drip water in caves can be taken as the boundary transition point of the cold and warm changes. These can be divided into the two time periods according to the character of the oxygen isotope records: (1) For the time period of 60,500-28,080yr B.P., the average value of $\delta^{18} \mathrm{O}$ is $-5.94 \%$ (PDB), the lowest value is close to $-8.02 \%--10.70 \%$ (PDB) and the highest value is close to $-2.65 \%$ - $-4.48 \%$ o (PDB). The $\delta^{18} \mathrm{O}$ value represents a negative drift trend, and the high oscillation has illustrated that both the strong and weak change ranges of the Asian summer monsoon are obtained in response to the relatively warm wet interstade of the last glacial period or MIS3 in the area. (2) During the time period of $28,080-11,270 \mathrm{yr}$ B.P., the average $\delta^{18} \mathrm{O}$ value is $-5.59 \%$ (PDB), the lowest value is close to $-8.02 \%--10.70 \%$ (PDB), and the highest value is close to $-3.27 \%--4.34 \%$ (PDB). The change of the $\delta^{18} \mathrm{O}$ curve shows a slight positive drift trend, while the undulation of the $\delta^{18} \mathrm{O}$ values mainly remains at about the average values, showing that the Asian summer monsoon was relatively calm, the Asian winter monsoon was very strong, and the air temperature was very low. The rainfall amount was reduced relatively in the dry and cold stage of the glacial maximum of the last glacial period in the world.

The records of the oxygen isotope curves indicate that the average value of $\delta^{18} \mathrm{O}$ from the Q4 and Q6 stalagmites is -5.83\%o (PDB) which is a much heavier isotope value than that of the same ages of other stalagmites from different areas. The average value of $\delta^{18} \mathrm{O}$ from the Q4 and Q6 stalagmites increased from 2\%o to 2.6\%o (PDB), compared to Dongge Cave and Yaman Cave of Libo county, within the karst slope zone of the plateau edge in southern Guizhou. Values increased for $1 \%$ (PDB) or $2 \%$ (PDB) in comparison to Panlong Cave and Xianshui Cave in Guilin area (which is the karst peak forest-plain area) and the coastal cities influenced by the Asian monsoon. There was also an increase of 5\% (PDB) compared to Xiashuilong Cave of Xuanwei in the Yunnan-Guizhou plateau, and an increase of 7.4\% (PDB) compared to Xianren Cave of Lugu Lake in Yunnan plateau which is strongly affected by the India monsoon. Meanwhile, the average $\delta^{18} \mathrm{O}$ value from the Q4 and Q6 stalagmites in general rose from 1.5\% (PDB) to 5\% (PDB) (Figure 1, Table 2, 3 ) compared with the oxygen isotopes of the present drip water and the present carbonate deposits and the new stalagmites in caves and rainwater above the areas (Yuan Daoxian et al., 1999; Wang Yongjin 
Table $1{ }^{230}$ Th ages of Q4 and Q6 stalagmites from Qixin Cave of Duyun, Guizhou*.

\begin{tabular}{llcccccc}
\hline Sample & $\begin{array}{l}\text { depth } \\
(\mathrm{cm})\end{array}$ & $\begin{array}{c}238 \mathrm{U} \\
(\mathrm{ppb})\end{array}$ & $\begin{array}{c}232 \mathrm{Th} \\
(\mathrm{ppt})\end{array}$ & $\begin{array}{c}{ }^{234} \mathrm{U} \\
\text { (measured) }\end{array}$ & $\begin{array}{c}{ }^{230} \mathrm{Th} /{ }^{238} \mathrm{U} \\
(\text { activity })\end{array}$ & $\begin{array}{c}\delta^{234} \mathrm{U}^{* *} \\
\text { (initial) }\end{array}$ & $\begin{array}{c}230 \mathrm{Th} \text { Age (yr) } \\
\text { (corrected })\end{array}$ \\
\hline Q4-1 & 1.0 & $442.0 \pm 1.0$ & $87 \pm 19$ & $519.3 \pm 2.3$ & $0.1642 \pm 0.001$ & $537.9 \pm 2.4$ & $12,400 \pm 80$ \\
Q4-2 & 2.0 & $2042 \pm 4.0$ & $1297 \pm 21$ & $596.8 \pm 2.2$ & $0.1983 \pm 0.0008$ & $621.5 \pm 2.3$ & $14,350 \pm 60$ \\
Q4-3 & 3.0 & $268.2 \pm 0.6$ & $2738 \pm 23$ & $513.0 \pm 3.0$ & $0.2005 \pm 0.0056$ & $535.5 \pm 3.3$ & $15,210 \pm 470$ \\
Q4-4 & 4.5 & $281.5 \pm 0.6$ & $1804 \pm 15$ & $562.2 \pm 2.1$ & $0.2134 \pm 0.0012$ & $587.8 \pm 2.2$ & $15,790 \pm 110$ \\
Q4-5 & 7.0 & $1851 \pm 6.0$ & $4204 \pm 19$ & $546.3 \pm 2.9$ & $0.2416 \pm 0.0012$ & $575.4 \pm 3.1$ & $18,330 \pm 110$ \\
Q4-6 & 18.0 & $656.0 \pm 1.0$ & $4930 \pm 22$ & $459.7 \pm 2.4$ & $0.3366 \pm 0.0016$ & $497.9 \pm 2.6$ & $28,080 \pm 170$ \\
Q4-7 & 26.0 & $458 \pm 1$ & $3759 \pm 17$ & $427.9 \pm 2.6$ & $0.3907 \pm 0.0017$ & $471.2 \pm 2.9$ & $34,170 \pm 210$ \\
Q4-8 & 35.0 & $1288 \pm 3$ & $2976 \pm 19$ & $460.2 \pm 2.1$ & $0.4362 \pm 0.0017$ & $512.3 \pm 2.3$ & $37,950 \pm 180$ \\
Q4-9 & 39 & $265.6 \pm 0.6$ & $2027 \pm 18$ & $475.0 \pm 2.6$ & $0.4554 \pm 0.0025$ & $531.1 \pm 3.0$ & $39,340 \pm 280$ \\
Q4-10 & 47.0 & $5546 \pm 19$ & $10950 \pm 35$ & $458.1 \pm 2.6$ & $0.4795 \pm 0.0021$ & $516.7 \pm 3.0$ & $42,540 \pm 250$ \\
Q4-11 & 49.0 & $303.6 \pm 0.8$ & $2336 \pm 18$ & $477.2 \pm 3.0$ & $0.5040 \pm 0.0026$ & $540.9 \pm 3.4$ & $44,330 \pm 310$ \\
Q6U-1 & 1.0 & $470.4 \pm 0.9$ & $19 \pm 16$ & $584.9 \pm 2.2$ & $0.1566 \pm 0.0010$ & $603.9 \pm 2.2$ & $11,290 \pm 80$ \\
Q6U-2 & 8.4 & $6330 \pm 23$ & $3433 \pm 16$ & $584.0 \pm 2.5$ & $0.1705 \pm 0.0008$ & $504.5 \pm 2.4$ & $12,340 \pm 60$ \\
Q6U-3 & 11.5 & $502 \pm 1$ & $24 \pm 14$ & $485.5 \pm 2.3$ & $0.1742 \pm 0.0009$ & $504.5 \pm 2.4$ & $13,530 \pm 80$ \\
Q6U-4 & 26.7 & $535.4 \pm 0.7$ & $515 \pm 17$ & $574.1 \pm 2.2$ & $0.2154 \pm 0.0012$ & $600.5 \pm 2.3$ & $15,900 \pm 100$ \\
Q6U-5 & 40.5 & $392.9 \pm 0.9$ & $925 \pm 19$ & $532.0 \pm 2.9$ & $0.2389 \pm 0.0016$ & $560.2 \pm 3.1$ & $18,280 \pm 140$ \\
Q6U-6 & 79.5 & $398 \pm 1$ & $1608 \pm 13$ & $516.0 \pm 2.4$ & $0.3087 \pm 0.0016$ & $553.1 \pm 2.6$ & $24,470 \pm 150$ \\
Q6U-7 & 114.5 & $227.2 \pm 0.5$ & $1729 \pm 11$ & $531.4 \pm 2.5$ & $0.4081 \pm 0.0019$ & $583.5 \pm 2.8$ & $33,080 \pm 200$ \\
Q6U-8 & 126.8 & $6770 \pm 36$ & $2362 \pm 14$ & $482.5 \pm 2.8$ & $0.4522 \pm 0.0029$ & $538.6 \pm 3.2$ & $38,910 \pm 300$ \\
Q6U-9 & 158.5 & $9217 \pm 29$ & $492 \pm 11$ & $667.1 \pm 2.0$ & $0.5924 \pm 0.0024$ & $760.3 \pm 2.3$ & $46,460 \pm 230$ \\
Q6U-11 & 204.5 & $289.8 \pm 0.6$ & $55 \pm 14$ & $526.3 \pm 2.5$ & $0.5969 \pm 0.0023$ & $610.7 \pm 2.9$ & $52,470 \pm 280$ \\
Q6U-12 & 243.5 & $295.1 \pm 0.8$ & $349 \pm 15$ & $483.5 \pm 3.2$ & $0.6413 \pm 0.0035$ & $572.3 \pm 3.9$ & $59,680 \pm 460$ \\
\hline
\end{tabular}

$* \lambda_{230}=9.1577 \times 10^{-6} \mathrm{Y}^{-1} ; \lambda_{234}=2.8263 \times 10^{-6} \mathrm{Y}^{-1} ; \lambda_{238}=1.55125 \times 10^{-6} \mathrm{Y}^{-1} ; * * \delta^{234} \mathrm{U}=\left(\left[{ }^{234} \mathrm{U} /{ }^{238} \mathrm{U}\right]_{\text {active }}-1\right) \times 1000$.

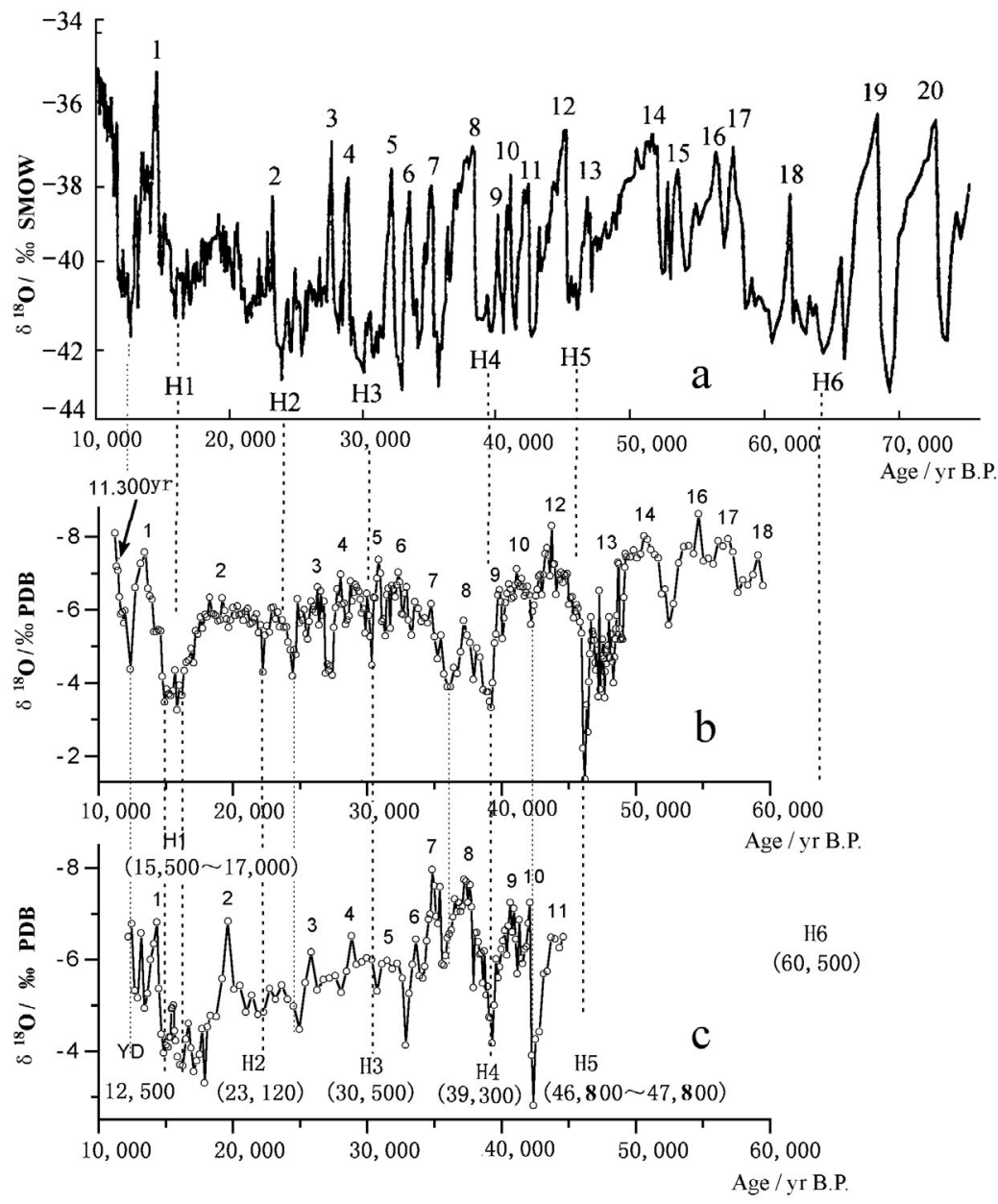

Figure 2 The comparison of the oxygen isotope record of two stalagmites in Guizhou with the Greenland ice core -GISP2 core. a-GISP2 core (Dansgaard W. et al., 1993; Stuiver M., Grootes P.M., 2000); b, c- $\delta^{18} O$ record of Q6 and Q4 stalagmites respectively. 
et al., 2001; Li Bin et al., 2000; Zheng Shuhui et al., 1983; Lin Yushi et al., 2001).

The research area is located in the southeastern edge zone of the Yunnan-Guizhou plateau. The western part of the area is mainly separated by the Daliangshang-Wumenshang-Meihuashang mountain ranges of nearly NS or NE orientation. The area is influenced by the quasi-stationary front of Kunming or the climatic front of YunnanGuizhou in the western part of the Yunnan-Guizhou plateau, and by the intruding Indian monsoon. For this reason, the characteristics of the oxygen isotope records from the Q4 and Q6 stalagmites show that the intrusion of the Indian summer monsoon into the study area was gradually weakened and made smaller contributions to the annual rainfall. The southeastern part of the research area is the karst slope zone of the southern Guizhou plateau. This region is mainly affected by the particular topography of the plateau and the height above sea level. When the rainfall of the Asian summer monsoon and the warm-wet air masses of the tropical rainfall meet with the air current of the plateau area, the change in the air current results in a gradual weakening of the Asian summer monsoon which makes smaller contributions to the annual rainfall. However, the influence of the summer rainfall of the Eastern Asian monsoon and the warmwet air masses of the tropical rainfall on the karst slope (under $800 \mathrm{~m}$ above sea level) area is much larger. Therefore, the Eastern Asian monsoon provides greater contributions to the annual rainfall for the karst slope zone of Libo in southern Guizhou. The climate change trend (Tables 2 and 3) shows that this region is mainly affected by the warm and wet air masses and the cold fronts of the winter monsoon or cold air masses from the northwest. The Eastern Asian winter monsoon obviously prevails in the area and the $\delta^{18} \mathrm{O}$ is isotopically heavier, so that the air temperature is reduced and the rainfall decreased. The distinctive climatic characteristic in this area is formed under the effect of geographical environment and atmospheric circulation.

\section{Comparison of isotope records of the two stalagmites with the GISP2 ice core or Heinrich's events in the North Atlantic Ocean}

The sediment cores of the North Atlantic Ocean in the last glacial period often contained multi-layer sediments with increasingly coarse grain sizes or clastics and rapidly decreasing foraminifer levels. The rapid climate fluctuation of the Heinrich events (Heinrich H., 1988; Bond G. et al., 1992; Dansgaard W. et al., 1993) within these time spans of several hundred years or the previous thousand years cannot be explained by the Milankovitch Theory or the Astronomical Theory. Bond et al. (1992) considered that the ice-rafted debris layers of Heinrich events were carried out by massive discharges of icebergs into the North Atlantic Ocean, and the ice flows moved toward the south and dissolved. Meantime, the temperature and salinity reduction of the vast sea or ocean surfaces resulted in the extensive areas of the cold events in the region of the circum-North Atlantic Ocean, with formation ages that are in accord with the Heinrich cold events of the Dansgaard-Oeschger cycles in the Greenland ice core-GISP2 core (Bond G., et al., 1993). Broecker et al. (1994) thought that the Heinrich cold events were reflections of the global climate (Broecker W.S., 1994). New studies have indicated that there exist records of the cold events in loess beds of North China, ice cores of Qinghai-Xizang plateau, sediments of South China Sea, and lake sediments (Porter, S. and An Z. S., 1995; Yao Tandong et al., 1997; Linsley B. K., 1996; Gu Zhaoyan et al., 1998), but there are similar records from some stalagmites of caves in South China as well.
Table 2 Oxygen isotopes of present drip water in caves and rain water (Zhang Meiliang et al., 1998; Yuan Daoxian et al., 1999; Zheng Shuhui et al., 1983).

\begin{tabular}{|c|c|c|c|c|}
\hline $\begin{array}{l}\text { Sampling } \\
\text { position }\end{array}$ & Types of samples & $\begin{array}{l}\text { Sampling } \\
\text { date }\end{array}$ & $\begin{array}{c}\text { D } \\
(\text { SMOW \% })\end{array}$ & $\begin{array}{c}\delta^{\mathbf{1 8}} \mathbf{O} \\
(\mathrm{SMOW} \%)\end{array}$ \\
\hline $\begin{array}{l}\text { Qixin cave } \\
\text { of Guizhou }\end{array}$ & $\begin{array}{l}\text { present drip } \\
\text { water in caves }\end{array}$ & $12 / 30 / 99$ & -35.6 & -5.74 \\
\hline $\begin{array}{l}\text { Dongge cave } \\
\text { of Guizhou } \\
\text { Longaian cave }\end{array}$ & same as above & $12 / 28 / 99$ & -57.6 & -8.52 \\
\hline of Guizhou & same as above & $12 / 30 / 99$ & -53.3 & -7.75 \\
\hline $\begin{array}{l}\text { of Guizhou } \\
\text { Xianshui cave }\end{array}$ & same as above & $12 / 30 / 99$ & -44.0 & -7.08 \\
\hline $\begin{array}{l}\text { of Guilin } \\
\text { Xianshui cave }\end{array}$ & same as above & $10 / 09 / 97$ & -35.60 & -6.16 \\
\hline $\begin{array}{l}\text { of Guilin } \\
\text { Panlong cave }\end{array}$ & same as above & $10 / 09 / 97$ & -38.3 & -6.66 \\
\hline of Guilin & same as above & 1993-1995 & -36.86 & -5.66 \\
\hline Lhasa area* & rain water & 2/9/80 & -93.30 & -13.43 \\
\hline Kunming area* & rain water & $27 / 9 / 80$ & -72.0 & -10.02 \\
\hline Guiyang area & rain water & & & -8.30 \\
\hline $\begin{array}{l}\text { Beijing area* } \\
\text { Yanshang area }\end{array}$ & rain water & $28 / 8 / 80$ & -63.0 & -9.29 \\
\hline of Guilin & rain water & 1993-1998 & -31.4 & $\begin{array}{l}-5.65- \\
-6.10\end{array}$ \\
\hline \multicolumn{2}{|c|}{ Guangzhou area* } & $23 / 9 / 80$ & -44.6 & -6.32 \\
\hline
\end{tabular}

Table 3 The characteristics of carbon and oxygen isotope from new stalagmites and present carbonate deposit (Zhang Meiliang et al., 1998; Yuan Daoxian et al., 1999; Li Bin et al., 2000; Lin Yushi et al., 2001) in caves.

\begin{tabular}{|c|c|c|c|c|}
\hline $\begin{array}{l}\text { Sampling } \\
\text { position }\end{array}$ & $\begin{array}{l}\text { Types of } \\
\text { samples }\end{array}$ & $\begin{array}{l}\text { Sampling } \\
\text { date }\end{array}$ & $\begin{array}{c}\delta^{18} \mathrm{C} \\
(\mathrm{SMOW} \%)\end{array}$ & $\begin{array}{c}\delta^{18} \mathbf{O} \\
(\mathrm{SMOW} \%)\end{array}$ \\
\hline $\begin{array}{l}\text { Panlong cave } \\
\text { of Guilin }\end{array}$ & $\begin{array}{l}\text { Present carbonate } \\
\text { deposit in cave }\end{array}$ & $94-95$ & -6.76 & $-5.89^{*}$ \\
\hline $\begin{array}{l}\text { Xianshui cave } \\
\text { of Guilin } \\
\text { Xianshui cave }\end{array}$ & same as above & $10 / 09 / 97$ & -8.96 & $-6.18^{*}$ \\
\hline $\begin{array}{l}\text { of Guilin } \\
\text { Dongge cave }\end{array}$ & same as above & $10 / 09 / 97$ & -10.17 & $-6.35^{*}$ \\
\hline $\begin{array}{l}\text { of Guizhou } \\
\text { Panlong cave }\end{array}$ & same as above & $30 / 12 / 99$ & -6.18 & $-7.73^{*}$ \\
\hline $\begin{array}{l}\text { of Guilin } \\
\text { Xianshui cave }\end{array}$ & No.1 stalagmite & $16 / 05 / 94$ & -7.26 & $-6.14^{*}$ \\
\hline $\begin{array}{l}\text { of Guilin } \\
\text { Dongge cave }\end{array}$ & No.1 stalagmite & $10 / 09 / 97$ & -6.06 & $-7.76^{*}$ \\
\hline $\begin{array}{l}\text { of Guizhou } \\
\text { Yaman cave }\end{array}$ & No.4 stalagmite & $28 / 12 / 99$ & -5.06 & $-7.73^{*}$ \\
\hline $\begin{array}{l}\text { of Guizhou } \\
\text { Qixin cave }\end{array}$ & No.1 stalagmite & $30 / 12 / 99$ & -10.35 & $-8.45^{*}$ \\
\hline $\begin{array}{l}\text { of Guizhou } \\
\text { Xingren cave }\end{array}$ & No.4 stalagmite & 20/04/97 & -5.79 & -5.85 \\
\hline $\begin{array}{l}\text { of Yunnan } \\
\text { Xiashuilong ca }\end{array}$ & $\begin{array}{l}\text { No.1 stalagmite } \\
\text { ave }\end{array}$ & 7/07/99 & -6.46 & $-13.55^{* *}$ \\
\hline $\begin{array}{l}\text { of Yunnan } \\
\text { Xingren cave }\end{array}$ & No.1 stalagmite & $15 / 11 / 99$ & -5.85 & $-11.10 * *$ \\
\hline $\begin{array}{l}\text { of Yunnan } \\
\text { Xiashuilong ca }\end{array}$ & $\begin{array}{l}\text { Present stalagmite } \\
\text { ave }\end{array}$ & $7 / 07 / 99$ & -4.32 & $-17.53^{* *}$ \\
\hline of Yunnan & Present stalagmite & $15 / 11 / 99$ & -6.24 & $-10.98 * *$ \\
\hline
\end{tabular}

* Influence area of the Eastern Asian monsoon.

** Influence area of the Indian or Southwest monsoon. 


\section{Comparison of Heinrich events from two stalagmite records with GISP2 ice core}

The dating ages of TIMS-U series and the characteristics of the sedimentary cycles and the curve changes of the oxygen isotope records from the Q4 and Q6 stalagmites have shown that the $\delta^{18} \mathrm{O}$ curves from the two stalagmites agree very well. The position of peaks and valleys and the oscillation amplitude of the $\delta^{18} \mathrm{O}$ curves are very well related. The several dry and cold events of the records from the two stalagmites occurred ca. 15,500-17,890 yr, $22,000-24,320 \mathrm{yr}, 30,740 \mathrm{yr}, 38,650-39,340 \mathrm{yr}$ and 46,200-47,700 yr respectively. The comparison of the above cold events with Heinrich's events H1-H5 (ages of 14,300 yr or 16,000 yr, 21,000 yr or $24,000 \mathrm{yr}, 28,000 \mathrm{yr}$ or $30,000 \mathrm{yr}, 39,000 \mathrm{yr}$ or $41,000 \mathrm{yr}$ and 51,000 $\mathrm{yr}$ or $52,000 \mathrm{yr}$, respectively) of deep sea sediment cores in the North Atlantic Ocean have a very good corresponding relation (Table 4). Meanwhile, these events with Weinan loess of North China and the cold events of the stalagmite record from Tangshan Cave in Nanjing also have a corresponding relationship.

The $\delta^{18} \mathrm{O}$ curves of the Q4 and Q6 stalagmites and the GISP2 ice core (GRIP) show a very similar change (Figure 2) and correspond to the time sequence range of the same ages. The $\delta^{18} \mathrm{O}$ curve of the GISP 2 ice core represents 5 extremes of dry and cold climate and is considered to be the polar region climate response to the floating ice debris events H1-H5 in the North Atlantic Ocean (Dansgaard $\mathrm{W}$ et al., 1993). These five floating ice debris events are obviously reflected in the $\delta^{18} \mathrm{O}$ curve records from the Q4 and Q6 stalagmites. Each cold event in the Dansgaard-Oeschger cycles of the Greenland ice core-GISP2 ice core (Bond G, et al., 1993) in general lasts from $200 \mathrm{yr}$ to $2,000 \mathrm{yr}$, and corresponds with the cold events found in the $\delta^{18} \mathrm{O}$ curves of the Q4 and Q6 stalagmites. For instance, the warm peaks from 1 to 18 (IS) are found in the $\delta^{18} \mathrm{O}$ curves of the Q4 and Q6 stalagmites, with the warm peak values $\left(\delta^{18} \mathrm{O}\right.$ the negative drift) representing the maximum stage of the Asian summer monsoon. This could correspond with the relatively warm interstadial events in the Dansgaard-Oeschger cycles of the Greenland ice core-GISP2 ice core during the last glacial period. The low valley areas of the $\delta^{18} \mathrm{O}$ curve record (i.e. the $\delta^{18} \mathrm{O}$ heavier drift area) represent the maximum stage of the Asian winter monsoon and correspond with the cold events in the Dansgaard-Oeschger cycles of GISP2 core and
Heinrich cooling events of the deep sea sediments cores in the North Atlantic Ocean during the last glacial period. The recorded TIMS-U series ages of the various events from the two stalagmites are completely in accord with the event ages by high-resolution survey in the Greenland ice core-GISP2 ice core in the last glacial period.

Heinrich events occurred in the coldest stage of the DansgaardOeschger cycles of the GISP2 ice core during the last glacial period and represented the end of the former cycle, and the subsequent warming period represented the beginning of the new cycle. The above records indicate that the cold events probably reflect short periodical climate oscillation events of global significance according to their distributional expanse and comparable nature.

\section{The Younger Dryas event record and Termination 1 from the two stalagmites}

The Younger Dryas event approximately occurred as a short cooling period ca. 12,500 yr B.P., and was the last cold event of the transition from the last glacial period to the postglacial period. Recently, studyies showed that the Younger Dryas event had influenced climate in South America, of Antarctic ice (Harvey L.D.D. 1989; Lorius C.A., 1985), the Sulu Sea (Kudrass H.R., et al., 1991) and the South China Sea. Therefore, this represents an abrupt cooling event of global significance. The ages and $\delta^{18} \mathrm{O}$ records from the Q4 and Q6 stalagmites have shown that the Younger Dryas event occurred ca. 12,800-11,600 yr B.P. and was a cooling event of the last Deglacial (period) climate in the process of the overall warming. The air temperature from $11,600 \mathrm{yr}$ B.P. to Termination 1 (i.e. $11,300 \mathrm{yr}$ B.P.) of the last deglacial period rapidly rose again and followed the development or evolution stage of the Holocene Epoch.

Termination 1 is the end or termination point of the last glacial period cycle that can be easily confirmed with the records of the marine oxygen isotopes or the oxygen isotopes of ice cores. The curves of the high resolution oxygen isotope records from stalagmites in South China also indicate the very clear, sudden change point in the curve. Air temperature warmed in a short time (during $200-300 \mathrm{yr}$ ) after the Younger Dryas event. The $\delta^{18} \mathrm{O}$ records of stalagmites in South China changed from heavier to lighter very rapidly. The change range of the $\delta^{18} \mathrm{O}$ values from the Q4 and Q6 stalagmites was from $2.14 \%$ to $4 \%$, being the largest change in the

Table 4 The comparison of the ages from Q4 and Q6 stalagmites with the Heinrich layers in the North Atlantic Ocean and Weinan loess beds in the north of China (Bond G. et al., 1992; Porter, S. and An Z. S., 1995).

\begin{tabular}{|c|c|c|c|c|c|c|}
\hline \multirow[t]{2}{*}{ Name } & \multicolumn{6}{|c|}{ Ages of the sudden climate events (yr B.P.) } \\
\hline & YD & H1 & H2 & H3 & H4 & H5 \\
\hline \multicolumn{7}{|l|}{ Ages of Heinrich } \\
\hline layers (DSDP609 hole) & & 14,300 & 21,000 & 28,000 & 41,000 & 52,000 \\
\hline Schultz H et al. (1998) & & 16,000 & 24,000 & 30,000 & 39,000 & 51,000 \\
\hline Bond G. et al. & & 16,800 & 24,100 & 30,100 & 35,900 & 50,000 \\
\hline Column B of Weinan & & & & & & \\
\hline Loess in China & & $13,300-14,100$ & $20,400-21,900$ & $28,900-30,800$ & $36,900-40,400$ & $50,600-54,500$ \\
\hline \multicolumn{6}{|l|}{ Zeketai loess in China } & 47,800 \\
\hline $\begin{array}{l}\text { Wang Yongjin et al. } \\
\text { (2001) }\end{array}$ & & 16,200 & 24,200 & 30,500 & 38,900 & \\
\hline $\begin{array}{l}\text { Zhang Meiliang et al. } \\
(1998 ; 1999)\end{array}$ & 10,800 & $15,300-16,200$ & $21,000-25,000$ & $29,000-32,000$ & $36,700-41,000$ & \\
\hline $\begin{array}{l}\text { Q4 stalagmite } \\
\text { of Qixin cave }\end{array}$ & 12,500 & $15,890-17,890$ & $22,000-24,320$ & 30,740 & $38,650-39,470$ & \\
\hline $\begin{array}{l}\text { Q6 stalagmite } \\
\text { of Qixin cave }\end{array}$ & 12,500 & $15,500-17,000$ & $22,250-24,000$ & 30,370 & 39,200 & $46,200-47,700$ \\
\hline $\begin{array}{l}\text { Adopting value } \\
\text { of this paper }\end{array}$ & 12,500 & $15,500-17,500$ & 23,120 & 30,500 & 39,300 & $46,200-47,700$ \\
\hline
\end{tabular}


record of the two stalagmites. These compare well with the records from the P1 stalagmite of Panlong Cave and the X1 stalagmite of Xiangshui Cave in Guilin (Zhang Meiliang et al., 1998; Yuan Daoxian et al., 1999), from the D4 stalagmite of Dongge Cave , the L1 stalagmite of Longquan Cave, and the Y1 stalagmite of Yaman Cave in Libo, Guizhou (Figure 1).

The results of the dating ages and the oxygen isotope records from the two stalagmites have shown that the stage after 15,500 yr B.P. marked the end of the Last glacial period and the Global climate become warmer. The $\delta^{18} \mathrm{O}$ records of the stalagmites gradually become lighter with the most negative value obtained at about $13,000 \sim 14,000 \mathrm{yr}$ B.P. This indicates that the Eastern Asian summer monsoon was very strong, the air temperature rose, the rainfall increased, and the $\delta^{18} \mathrm{O}$ value was lighter. The following $\delta^{18} \mathrm{O}$ values rapidly became heavier at about $12,500 \mathrm{yr}$ B.P. and dropped to the low valley value of the last glacial maximum stage. Hereafter, the $\delta^{18} \mathrm{O}$ value rapidly became light again and entered the MIS1 stage of the Holocene Epoch. The borderline age of MIS1/MIS2 can be clearly confirmed to be $11,300 \mathrm{yr}$ B.P. according to the record of the dating ages from the two stalagmites. The low valley value at about 12,500 yr B.P. obviously compares with the Younger Dryas event from the high latitude regions.

\section{Conclusion}

The study results of TIMS-U series dating age and the oxygen isotope analysis from the Q4 and Q6 stalagmites of Qixin Cave in Duyun region of southern Guizhou have shown that the rising and declining evolution history of the Eastern Asian summer monsoon during the last glacial period was one of instability, similar to the climate change of the Polar region and the North Atlantic Ocean. The changing strength of the Eastern Asian summer monsoon had a large amplitude, and high frequency oscillation or vibration was the key before the MIS2 stage. The climate change of the Eastern Asian summer monsoon was relatively weakened and the Eastern Asian winter monsoon relatively strengthened, and the MIS2 stage was marked by an extremely harsh dry and cold climate. The cold events during the last glacial period included the Younger Dryas and Heinrich cold events (H1-H5) in the area of southern Guizhou. The formation age and duration time of the cold events were able to be clearly determined.

The $\delta^{18} \mathrm{O}$ values from the Q4 and Q6 stalagmites of the Qixin cave in southern Guizhou recorded the evolutionary history of the Eastern Asian monsoon change, with the $\delta^{18} \mathrm{O}$ values that not only recorded the abrupt cold events but also a series of warm interstadial events. This indicates that the stronger stage of the Eastern Asian monsoon recorded in the area compared well with the warm interstadial events of the Dansgaard-Oeschger cycles of the GISP2 ice core record during the last glacial period. The climate changes reflected in the $\delta^{18} \mathrm{O}$ value records from the two stalagmites during the last glacial period, over varying time scales, are completely in accord with the climate changes of the GISP2 core record.

The study results have indicated that the driving mechanism of the Eastern Asian paleo-monsoon circulating current changes is in accord with global changes recorded in other areas and the direct mechanism of the paleo-monsoon climate changes might come from the changes of the Global ice volume. This might be mainly affected or controlled by various factors including the sunshine radiation strength in the low-latitude Northern Hemisphere, the southern extention of the ice-rafted event in the North Atlantic, and changes of the Equatorial Pacific sea surface temperature. The evidence is mainly as follows: (1) The global ice volume reduces and then results in a more intensive East Asian summer monsoon in eastern China when the sea water in the South Pole and the vast sea surfaces increase in temperature. (2) These event records from the stalagmites in the south of Guizhou, some stalagmites in the area of Guilin (Zhang Meiliang et al., 1998; Yuan Daoxian et al., 1999), stalagmites of Nanjing (Wang Yongjin et al., 2001), from Weinan loess or
Lishi loess section (Guo Zhengtang et al., 1996; Porter, S. and An Z. S. 1995) in North China, and the Sulu sea sediments (Lu Houyuan et al., 1996; Kudrass H R et al., 1991) are all analogous to the record reports of the ice-rafted event in the North Atlantic ocean. This has shown that the paleo-monsoon circulation in China was influenced by the changes of the global ice amount and massive discharges of icebergs into the North Atlantic Ocean which caused the changes of the sea water temperature. (3) High resolution records of the Sulu sea oxygen isotopes (Kudrass H R et al., 1991;Yao Tandong et al., 1997) are shown as the best record of the global ice amount changes. The record changes of the stalagmites from Qixin Cave and Dongge Cave in southern Guizhou, some stalagmites from Xiangshui Cave (Zhang Meiliang et al,1998), Panlong Cave in the area of Guilin, and a stalagmite from Tangshan Cave in Nanjing (Wang Yongjin et al., 2001) correlate well and support his viewpoint.

The records of the cold and warm events from the two stalagmites in southern Guizhou have indicated that the changes of the Eastern Asian Paleo-monsoon circumfluence were also affected by the climatic oscillation or vibration of the North Atlantic Ocean and have good tele- connection with the paleo-climate changes that occurred in the north polar region.

The time sequence of paleo-climate changes since $60,500 \mathrm{yr}$ B.P. in southern Guizhou has been established according to TIMS-U series ages and the data of the oxygen isotope analysis from the Q4 and Q6 stalagmites. The boundary ages of MIS2/MIS3 and MIS1/MIS2 and Termination 1 during the last glacial period have been determined clearly, with borderline ages of $28,080 \mathrm{yr}$ B.P. and 11,300 yr B.P. respectively, and confirmed that there also exist records of the cold events in the Eastern Asian monsoon climate region of South China during the last glacial period that could correspond to the Heinrich events H1-H5 of the North Atlantic Ocean.

\section{Acknowledgements}

This work was supported by "The construction of keeping storeroom of the stalagmite samples in cave, China", a project of Science and Technology Ministry (Grant No. 2003 DEB6J069), by IGCP-448 "World Correlation of Karst Geology and Its Relevant Ecosystem" and a key project of National Science Foundation of China (Grant No.40152002). We thank Dr. Chris Groves at Geography \& Geology Department of the Western Kentucky University, USA for his help with English correction.

\section{References}

Bond, G., Heinrich, H., Broecker, W.S., et al., 1992, Evidence for Massive Discharges of Icebergs into North Atlantic Ocean during the Last Glacial period. Nature, 360:245-249.

Bond, G., Broecker,W.S., Johnson,S., et al., 1993, Correlations between Climate Records from North Atlantic Sediments and Greenland Ice. Ibid., 365:143-147.

Broecker, W.S., 1994, Massive iceberg discharges as triggers for global climate change. Nature, 372:421-424.

Dansgaard, W., Johnsen, S.J., Clausen, H.B., et al., 1993, Comparison of oxygen isotope records from the GISP2 and GRIP Greenland ice core. Nature, 366:552-554.

Dansgaard,W., Johnsen, S.J., Clausen,H.B., et al., 1993, Evidence for general instability of past climate from a $250 \mathrm{ka}$ ice-core record. Nature, 364:218220 .

Gao Daode, Zhang Shicong, Bi Kong, et al., 1986, Karst in South Guizhou, China. Guiyang, Guizhou People's Publishing House: 5-40.

Guo Zhengtang, Liu Tungsheng, Wu Naiqin, 1996, Heinrich-rhythm pulses of climates recorded in Loess of the last two glaciations. Quaternary Sciences, (1): 21-23.

Gu Zhaoyan, Zhao Huimin, Wang Zhenhai, et al., 1998, Evaporation salt records of environmental response to climate change in Barkol lake basin, Northwestern China, Quaternary Sciences. (4):328-334.

Heinrich, H., 1988, Origin and consequence of cyclic ice rafting in the northeast Atlantic Ocean during the past 130000 years. Quaternary Research, 29: $142-152$. 
Harvey, L.D.D., 1989, Modelling the Younger Dryas. Quaternary Science Review, 8:137-149.

Jeffrey, A.D., Edwards, R.L., Emi Ito, Gonzalez, L.A., 1998, Climate and Vegetation History of the Midcontient from 75 to 25ka: A Speleothem record from Crevice Cave,Missouri, USA. Science, 282:185-187

Kudrass,H.R., Erlenkeuser, H., Vollbrecht, R., Weiss, W., 1991, Global nature of the Younger Dryas Cooling Event inferred from oxygen isotope data from Sulu Sea cores. Nature, 349:406-409.

Li Bin, Yuan Daoxian, Qin jiaming, et al., 2000, Oxygen and carbon isotopic characteristics of rainwater, drip water and present speleothems in a cave in Guilin area and their environmental meanings. Science in China, Ser. D, 43(3): 277-285

Lin Yushi, Zhang Meiliang, Qin Jiaming, et al., 2001, The record of paleoclimatic environment in Lugu lake area of Ninglang county, Yunnan, Carsologica Sinica , 20(3):174-182.

Linsley, B.K., 1996, Oxygen-isotope record of sea level and climate variations in Sulu sea over past 150,000 years. Nature, 380:234-237.

Lorius, C.A., 1985, A 150000-year climatic record from Antarctic ice. Nature, 316:591-596.

Lu Houyuan, Guo Zhengtang, Wu Naiqin, 1996, Paleo-monsoon evolution and Heinrich events: Evidence from the Loess plateau and the South China Sea. Quaternary Sciences, (1):11-20.

Porter, S., An Z.S., 1995, Correlations between Climate Events in the North Atlantic and China during the Last Glaciation. Ibid., 375, 305-308.

Schultz, H., Rad, U., Erlenkeuser, H., 1998, Correction between Arabian Sea and Greenland climate oscillations of the past 110000 years. Nature, 393: 54-57.

Stuiver, M., Grootes, P.M., 2000, GIPS2 oxygen isotope ratios. Quaternary Research. 53: 277 284.

Wang Yongjin, Wu Jiangying, Wu Jinquan, et al., 2001, Correlation between high-resolution climate records from a Nanjing stalagmite and GRIP ice core during the last glaciation. Science in China, Ser. D, 40(1):14-21.

Yao Tandong, Thompson L.G., Shi Yafeng, et al., 1997, The record study of climate change from Guliya ice core since the Last glacial period. Science in China, Ser. D (in Chinese), 27(5):447-452.
Ye Wei, Dong Guangrong,Yuan Yujiang,et al., 2000, Climate instability in the Yili region,Xinjiang during the last glacition. Chinese Science Bulletin, 45(17):1604-1609.

Yuan Daoxian, Qin jiaming, Lin Yushi, et al., 1999, High resolution paleoenvironmental reconstrction up to 200,000 years B.P. with speleothems from Guilin. Guangxi Teachers University Press,17-30.

Zhang Meiliang, Yuan Daoxian, Lin Yushi, et al., 1998, Ages and paleoclimatic meanings of a stalagmite from Xianshui cave at Guanyang county, Guilin. Carsologica Sinica, 17(4): 311-318.

Zheng Shuhui, Hou Fagao, Ni Baoling, 1983, Study on stable hydrogene and oxygen isotope in China, Chinese Science Bulletin. 28(3):801-806.

Zhang Meiliang is professor of karst environment geology at Institute of Karst Geology, Chinese Academy of Geological Sciences, China. He was born in 1956 and graduated from the Geological Department of Peking University in 1980. He has been engaged in scientific research of the regional geology of karst, palaeokarst, and palaeo-environment reconstruction for twenty years.

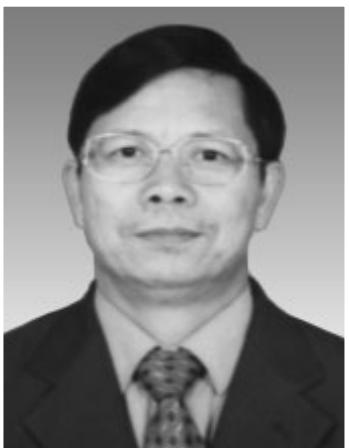

\section{Hutchison 'Young Scientist' Fund}

William Watt Hutchison, "Hutch" to his many friends around the world, was a Scots-born Canadian geologist who served Canada and the IUGS in myriad dynamic and creative ways. Most notably, he served as the IUGS Secretary General (1976-1980) at a pivotal time in its history, and as IUGS President (1984-1987). The same boundless energy, enthusiasm, skill in communications, and ability to foster teamwork that characterized his work with the IUGS also carried him to preeminent scientific administrative positions in the Canadian Government, where he served as Director General of the Geological Survey of Canada and as Assistant Deputy Minister of Earth Sciences. His distinguished career was terminated in 1987 by his untimely death at the age of 52, following a painful struggle with cancer.

One of Hutch's last wishes was to establish under IUGS auspices a memorial foundation intended to promote the professional growth of deserving, meritorious young scientists from around the world by supporting their participation in important IUGS-sponsored conferences. The first 3 beneficiaries of the Hutchison "Young Scientist" Foundation attended the 28th International Geological Congress (IGC) in Washington, D.C., in 1989.

Initially, earned interest on the funds available to the Hutchison Foundation were insufficient to sustain comparable grants every four years without seriously eroding the principal. For that reason, the IUGS made no grants from the Foundation for the 30th IGC (1996), preferring instead to strengthen the fund by allowing it to earn interest for a longer period of time and by appealing for donations from the international geologic community. Grants from the Foundation again supported deserving young scientists beginning with the 31st IGC (2000), and should continue for future Congresses. The IUGS would like to expand the resources of the Foundation to make it possible also to offer support to deserving young scientists to attend other important IUGS-sponsored scientific meetings. The Hutchison "Young Scientist" Foundation is a worthy cause that honors a fine, caring man and a distinguished, public-spirited scientist and administrator. The foundation also celebrates and promotes those things that gave Hutch the most professional satisfaction: geology, international scientific collaboration, and stimulating young minds.

The IUGS welcomes contributions to the Hutchison "Young Scientist" Foundation. Please send donations to:

Dr. Antonio Brambati

IUGS Treasurer

Dept. of Geological, Environmental and Marine Sci. (DiSGAM),

University of Trieste, 1-34127 Trieste, ITALY

Tel: +39040 558 2046; Fax: +39040 5582048

E-mail: brambati@univ.trieste.it

Checks in US dollars or Visa/Mastercard (please include account number and expiration date) are preferred in order to avoid the high cost of currency conversions. Residents of the U.S.A. are reminded that charitable gifts of this nature are tax deductible. 